\title{
Ho Chi Minh's thought on Great National Unity and its Significance to the Current Policy of National Unity of the Communist Party of Vietnam
}

\author{
Nguyen Van Dao* \\ Van Lang University, Ho Chi Minh City, Vietnam \\ *Corresponding Author \\ Nguyen Van Dao
}

\section{Article History}

Received: 18.08 .2020

Accepted: 25.08 .2020

Published: 29.08.2020

\begin{abstract}
The great national unity is a great spiritual value, an extremely precious tradition of our nation, which has been molded during the thousands of years of struggle for national construction and defense. Solidarity has become a great motivation, a philosophy of life and action for our people to overcome many incidents and ups and downs of natural disasters and enemy sabotage, to survive and develop sustainably. On the basis of Vietnamese revolutionary practices and world revolutionary practices, Ho Chi Minh's thought was soon formed about great national unity. This study focuses on analyzing Ho Chi Minh's view on the need for national unity, the role of national solidarity for the Vietnamese revolution and the application of this ideology by the Communist Party of Vietnam in the current period.
\end{abstract}

Keywords: Ho Chi Minh's thought, great national unity, ethnic unity policy, Communist Party of Vietnam.

\section{INTRODUCTION}

"Our people have ardent patriotic hearts. It's one of our precious traditions. From ancient times to the present, whenever the Fatherland was invaded, the spirit was ebullient, it combined into an extremely powerful, huge wave, it passed through all the dangers and difficulties, it submerged all ta traitor and bandits the country" [1]. From the reality of national history, Ho Chi Minh has affirmed that solidarity is one of the precious traditions of our nation, which has been molded on the basis of the passionate patriotism of generations of Vietnamese people.

Ho Chi Minh's thought on Great Solidarity is a system of points of view, principles, methods of education, organization, gathering of revolutionary forces in order to broadly unite all strata of society, promote to a high level the strength of the nation's nation, fighting for national independence, democracy, and socialism. Over the past 90 years, the Vietnamese Communist Party has creatively applied Ho Chi Minh's thought about great unity in the process of revolutionary leadership.

Ho Chi Minh's thought about great unity is the inheritance of the traditional solidarity and compassion of the Vietnamese people.

Ho Chi Minh's nation great unity is a consistent and consistent strategy for gathering revolutionary forces and a key factor for success. Patriotic tradition, kindness, the spirit of community cohesion of the nation are the important foundations of Ho Chi Minh's great unity.

Mutual love "blood flowing, soft intestines", "open lips, cold teeth", "broken hands, guts pain", "a drop of blood digging more than water" has penetrated the heart of Ho Chi Minh. He once asserted: "The South is the flesh of our flesh; is the blood of our blood" [2]. "The people of South Vietnam are Vietnamese people. Rivers can be shallow, mountains can wear, but that truth never changes" [3]. "We all share a common ancestor, all siblings ... No one can divide a family ... no one can divide our Vietnam" [4]. His steadfast will to blow up the indomitable power and spirit of our People in the divisive plot of hostile forces.

Copyright @ 2020: This is an open-access article distributed under the terms of the Creative Commons Attribution license which permits unrestricted use, distribution, and reproduction in any medium for non commercial use (NonCommercial, or CC-BY-NC) provided the original author and source are credited. 
Research has shown that it is the spirit of national solidarity of Vietnam that has created glorious victories of the people, and through Ho Chi Minh's thought on national solidarity to see the clarity of wisdom of him in the process of leading the Vietnamese revolution. The Communist Party of Vietnam has inherited that thought wisely in the context of the serious epidemic of the nCovid 19 epidemics, contributing to building a peaceful and prosperous Vietnam.

\section{LITERATURE REVIEW}

In his book "The Way of Revolution" - the book is considered as the handbook of revolutionaries, from the beginning to the end of the work, Ho Chi Minh always affirms that solidarity is an important factor. Written: "Vietnam proverb has the following sentences:" Group into rich, divided other into difficult "and "A tree no makes a mountain, many trees gather into a high mountain "... If we stand apart, then the power is small, but doing should not work. For example, if each person carries a pillar, a picture, each people of them separately, the tent is not the tent, the house is not the house. Group those columns, paintings, strength, make a house so spacious, and then you live together" [2].

Determination of "the personality of revolutionaries" has 23 criteria, of which Ho Chi Minh has affirmed that the most important criterion in the relationship for people is: "with everyone is tolerance and forgiveness" [6]. Deeply, Ho Chi Minh inherited the compassionate and traditional ethic tradition of the Vietnamese nation "Beat the people who run out, not beat the people back" to build and expand the solidarity block.

With a sharp political perspective, with a noble human spirit, throughout his life, Ho Chi Minh has constantly built and perfected a system of views on great national unity, actively spreading ideas solidarity in the whole Party and all levels of government, in all strata of people, including Vietnamese people far from the Fatherland.

Ho Chi Minh's thought on great national unity is an important part of his ideological system on the basic issues of the Vietnamese revolution. Studying the whole of his thought can see that the word "unity" is mentioned more than two thousand times and the word "great unity" is mentioned more than eighty times, which indicates interest with regard to the issue of solidarity in all conditions and all circumstances of history, at the same time, it clearly shows the strategic scope of his solidarity. Solidarity can be understood simply as gathering, uniting together, working together for a common purpose. Great solidarity is broad solidarity, which means to emphasize the composition, scale, and force of the solidarity block.

Ho Chi Minh said much about solidarity, great unity, but only once he defined the concept of great unity: "Great unity means first is the unity of all the people, but the great majority all of the people are workers, farmers, and working people. That is the root of great unity. It is like the background of a house, the root of a tree. But there has been a strong foundation, good roots, there must also unite other classes of people" [1]. The thought of great unity continues to be further concretized by Ho Chi Minh in terms such as: "great unity of all people", "unity of the whole people", "the unity of the nation", etc. Although the wording may be different, the connotations of the above concepts are consistent when asserting that the great unity bloc is for the entire Vietnamese people.

Thus, the great national unity under the Ho Chi Minh ideology is the great unity of ethnic groups, religions, caste, all sexes, all ages, all regions of the country, uniting all members of the great family Vietnamese people, whether living in the country or settling abroad into a solid group, on the basis of unity on common goals and basic interests.

\section{Ho Chi Minh pointed out the role of great national unity for the Vietnamese revolution}

When referring to the position and role of great national unity, Ho Chi Minh affirmed that the great national unity is a basic, consistent, long-term strategy, a vital issue, a decision to succeed of the revolution. It is a strategy to gather all forces to form and develop the great strength of the entire people in the struggle against the enemies of the nation and the people. According to him, solidarity constitutes the strength and the source of all success: "Unity is our unrivaled force to overcome difficulties and gain victory"; "unity, unity, great unity; Success, success, great success" [2].

The great national unity in Ho Chi Minh's thought is not simply a method of organizing and gathering forces, but rather an organic part, a thought throughout the revolutionary strategy line, He asserted: "Solidarity is a national policy, not a political trick" [3]. It can be said that national solidarity is both a prerequisite and vital factor for the cause of the revolution, as well as a guideline and goal, a leading task that the revolutionary career needs to orient and achieve.

For Ho Chi Minh, great unity is not a policy, a strategy derived from aspirations, subjective will of the leadership but a summary of the objective requirements of the revolutionary cause due to the masses do. If stemming from the needs of the revolutionary leadership, the great national unity will only stop as a political trick to achieve a certain purpose and intention. On the contrary, seeing national solidarity as a self-objective and objective requirement of the masses in the struggle for self-liberation, great unity is the cause of the people, by the people and for the people. Therefore, in the process of leading the revolution, the Requester must not at any time neglect the task of building a great 
national unity bloc. Building the great national unity bloc not only in awareness but concretized in every step, development stage of the revolution, he said: "We unite to fight for unity and independence of Country; we still have to unite to build our country" [4].

The cause of national liberation and reunification is a very important, huge, and extremely difficult job. That mission can only be successful when gathering the strength of unity of the entire nation because solidarity creates strength, creates a powerful force that can confront and overcome the enemy. The revolutionary practices answered between solidarity and success are closely related because the scope, extent, and scale of success depend primarily on the size and extent of the great unity. As the supreme leader of the resistance war against the French colonialists, Ho Chi Minh was deeply aware that solidarity not only created strength but was a matter that was crucial to survival, success, and defeat. Fight against the enemy. In order to explain a poor, backward country, Vietnam can confront and defeat an oligarch colonist with an absolute advantage in material and means of war, he said: "All Vietnamese people only have one heart: Determined not to be slaves, Only one will: Determined not to lose the country, Only one purpose: Determined the resistance to enlist unity and independence for the country. The concentricity of our people cast into a solid copper wall around the country. No matter how ferocious and cunning the enemy is, hitting them on that wall, they must fail" [5]. The reality of the Vietnamese revolution has answered, the more solidarity and victory, the greater the enemy, the more difficult and hardships need to unite closely, widely, and firmly. In the course of revolutionary leadership, he was particularly concerned about the issue of solidarity because solidarity is the key to victory and draws a big lesson and a vital rule of the Vietnamese people: "History tells us this lesson: Whenever our people unite all people like one, our country is independent and free. On the contrary, when our people are not united, they will be invaded by foreign countries" [1].

\section{Ho Chi Minh pointed out that the force of the great national unity bloc is the people, which takes the alliance between the working class and the peasant class and the intellectual team as the basis}

Inheriting and raising the traditional political thinking of his father: "The country takes the people as the root"; At the same time imbued with the Marxist principle of "Revolution is a festival of the masses", Ho Chi Minh sought the power and the magical handbook of the struggle for national liberation and national reunification in the countless forces enemy of the people: "In the sky, there is nothing more precious than the people. In the world, there is nothing stronger than the united force of the people" [3]. In Ho Chi Minh's thoughts, people and people have a very broad connotation. The terms are used to refer to all the people of Vietnam who are called "Lac Hong descendants". The idea of his great national unity is to unite all classes of people, classes, political parties, unions, peoples, religions, including those who have been lost in the past but have to know repentance, return to the cause of the nation. Unite in his thought is to unite widely, expand, and enlist all forces and divisions that can enlist. The principle of solidarity is broadly based on the similarity: "Anyone who honestly advocates peace, unity, independence, democracy, even though those people were previously against us, we are now also honest solidarity with them". "Those who are talented, competent, virtuous, and devoted to the Fatherland and to serve the people are united with them" etc [3].

According to President Ho Chi Minh, the great unity of the nation must be based on the supreme interests of the nation and the basic rights of the working people as a foundation, harmoniously combining personal interests and collective interests whole, part and whole, class and ethnic group, national and international. The foundation of the great national unity bloc continues to be affirmed: "Great unity means first of all the majority of the people, but the vast majority of our people are workers, peasants, and people of all strata. Other workers ", and later He added the foundation of the great national unity bloc is the alliance between workers, farmers, and intellectuals:" In the revolutionary career, in the career of building the master society. "That is, intellectual labor has an important and glorious role; and labor, agriculture, and intelligence need to unite closely into a mass" [2].

Thus, in Ho Chi Minh's thought, there is always a harmonious, close, and consistent combination between ethnic factors and class factors. National solidarity on the basis of taking the peasant union as the root, never forgetting class interests, but he also had a superior mindset before asserting that nationalism was a great driving force of the Vietnamese revolution Male.

According to him, the strength of the great national unity bloc is only promoted when gathered in the National Unity Front under the leadership of the Party. Both the nation and the entire people can only create great power, become the invincible force when organized into a coherent mass, deeply enlightened about the ideal goal, guided by the right political line, otherwise the masses of the population millions of people are just a few people without power, discrete.

Ever since Ho Chi Minh found a way to save the country and liberate the nation, Ho Chi Minh paid great attention to the gathering of the masses, bringing them to patriotic organizations suitable to the characteristics of each gender, age group, class, religion, etc. Covering all is the thought that wants to absorb a large number of people from all classes into the National United Front. The Front needs to gather a large number of people, who are more or less 
patriotic, the front needs to be a wide organization. Widely aimed to realize the unity of many organizations, many forces regardless of whether they are rich or poor, partisan, political trends....He said: "The front consists of all patriots, regardless of political orientation, beliefs, religion, social class, men and women and age" [4]. Therefore, the Front not only attracted all poor and oppressive working classes but also attracted the upper class of non-working people and a division in the ranks of the enemies. In the Front, the backbone and main strength of the great unity bloc is the bloc of the farm and labor union as the foundation, he said: "The main force in the national solidarity bloc is the peasantry, so the peasant union is the foundation of the United National Front" [4].

The relationship between the Front and the labor union reflects the social organization in a dialectical relationship between the nation and the class. In particular, separating or emphasizing the one-sided role of the Front or the labor union is not in accordance with the dialectic of revolutionary life, not in accordance with his principle of solidarity. Absolutely reducing the role and position of the labor union, lowering the role of the Front will lead to extremes, leftist, and isolated and narrow diseases. On the contrary, emphasizing and upholding the role of the Front, disregarding the labor union will lead to right and anarchism. He once said: "In the solidarity policy, it is necessary to oppose two false tendencies: loneliness, narrowness and unscrupulous solidarity" [4].

Among the rich forces of the Front, the Vietnamese Communist Party was identified as a member, because the Party was the most elite part of the working class. However, the Party is not an ordinary member, but a leader of the great unity bloc of the entire people. One of the Party's top tasks is to propagate and educate the masses to realize the need to unite; select appropriate forms and methods of organization in order to widely attract patriotic and progressive forces among the people; guide the great unity bloc to fight and create creative labor according to the objectives and tasks suitable to the sacred interests of the nation and the legitimate aspirations of the people. He also emphasized that the leadership of the Front is not for the Party itself, but it must be recognized by the people: "The Party cannot ask the Front to recognize its leadership, but must appear to be a central part most honest, most active, and most authentic. Only in the struggle and daily work, when the public widely acknowledges the right policy and the leadership capacity of the Party, the Party can gain leadership position" [3].

In short, the force that contributes to the strength of the great national unity is the entire people, in which the union of workers - farmers - intellectuals is the foundation gathered in a Unified Front under the leadership of Party. The reality has answered only on the basis of following this principle, the great national unity has a sustainable and lasting vitality.

\section{The manipulation of the Communist Party of Vietnam}

For 90 years of implementing a consistent and consistent strategy of great national unity, especially during more than 30 years of renovation, the Communist Party of Vietnam has consistently applied Ho Chi Minh's thought in terms of great national unity consistent with the situation, requirements, and tasks of the revolutionary cause, steadfast national independence, and socialism, for a Vietnam "rich, strong, democratic, equitable and civilized" country [5, 6].

In the process, in the spirit of "taking the people as the root", building and promoting the ownership of the working people, the principle of democratic negotiation is considered the "universal key" for the Vietnam Fatherland Front $[7,8]$. Nam gathered, united, and promoted the strength of the entire nation to make great victories in the struggle for national liberation, successfully conducting the resistance against the French colonialists and the anti-American resistance and national salvation., liberating the South, reuniting the country, the whole country went up to socialism, building "our country more properly, bigger and more beautiful" as President Ho Chi Minh wishes.

In fact, the extensive social mobilization and patriotic emulation movements launched and implemented by the Front and its member organizations have come to life more and more actively, by people of all strata response. In particular, solidarity helps each other in economic development, hunger eradication, and poverty alleviation, good leaves protect torn leaves, health insurance, social insurance, implementation of food hygiene and safety, health care protection of the people, protecting the environment and responding to climate change, preventing and combating crimes, drugs, prostitution, HIV/AIDS and other social evils, along with social movements "drink water to remember the source", "day for the poor", "Vietnamese give priority to using Vietnamese goods", "all people unite to build cultural life", "all people unite to build building new rural areas, civilized urban areas", "all people protect the national security", etc not only have practical effects, create community cohesion but also contribute to the idea of the great unity of the entire people ethnic groups penetrate deeply into the strata of the people, creating a driving force for rapid and sustainable national development, serving the cause of national construction and defense [9].

Great unity is the cause of the entire political system, including the Party, the government, the Fatherland Front and mass organizations; in which, the main motive for building, defending and developing the country is the great unity of the entire people on the basis of the alliance between workers and farmers and the Party-led intellectuals, 
harmoniously combining interests individuals, collectives and society, promoting all potentials and resources of all economic sectors, of the whole society. In order for the national unity bloc to be strong, to achieve social consensus, requires all members of it to respect and act on common principles and wills and each decision to be adopted must be "common denominator", reflecting and expressing the aspirations and interests of the whole society.

Therefore, in order to "strongly promote all resources and all creative potentials of the people to build and defend the Fatherland; taking the goal of building a peaceful, independent, unified and territorial Vietnam, "rich people, strong country, democracy, justice and civilization" as a similarity; respect for differences not contrary to the common interests of the nation and the nation; uphold the national spirit, patriotic tradition, humanity, and tolerance to gather and unite Vietnamese people inside and outside the country, strengthen close ties between the people and the Party, the State, and create births new force of the great unity bloc of the entire nation" $[7,10]$.

\section{CONCLUSION}

Thoroughly understanding, applying, and developing creatively Ho Chi Minh's thought about great national unity, the Party affirms: The great unity of the entire nation in Vietnam is the unity and attachment for all members ethnic groups, religions, caste, class, gender, all ages, all regions of the country, people in the Party and non-Party members, working people, retired people and all members of the giants Vietnamese national family, whether living in the country or abroad, into a solid, stable and long-term bloc in order to create the collective strength of the entire nation, successfully implementing the cause of building socialism and protecting defense of the Socialist Republic of Vietnam led by the Communist Party of Vietnam [10-13].

Within that great unity bloc, the working class, the peasantry and the intellectual class were the core force, the most numerous, and also the solid basis of the great unity bloc of the entire nation. Through this alliance, the Party and the State can gather and mobilize other working people to participate in state management, social ownership, and make the interests of the class closely associated with the interests of the people, creating high consensus in society. Therefore, our Party pointed out: "The great unity bloc of the entire nation on the basis of the alliance of the working class with the peasantry and the intellectual class under the leadership of the Party is a strategic line of the revolution. Vietnam; is the main source of strength, motivation and a decisive factor to ensure the sustainable victory of the cause of national construction and defense" $[12,13]$.

At present, in response to the demands of the revolutionary career in the new period, our Party continues to affirm that the great unity of the nation is a strategic issue of the revolution. The credo of building the country during the transition to socialism (Supplement, development in 2011) has summarized one of the great lessons of the Vietnamese revolution: "Constantly consolidating and strengthening the delegation unity: unity of the whole Party, unity of the whole people, national unity, and international solidarity. It is a valuable tradition and a great source of power for our country's revolution" $[12,13]$.

\section{REFERENCE}

1. Ho Chi Minh. (2000). The complete episode, episode 1. Hanoi: National politics.

2. Ho Chi Minh. (2000). The complete episode, episode 2. Hanoi: National politics.

3. Ho Chi Minh. (2000). The complete episode, episode 3. Hanoi: National politics.

4. Ho Chi Minh. (2011). The complete episode, episode 4. Hanoi: National Politics.

5. Communist Party of Vietnam. (2000). Complete Party Document, episode 7. Hanoi: National Politics.

6. Ministry of Foreign Affairs. (2008). Uncle Ho and diplomatic activities - Some memories of Uncle Ho. Hanoi: National politics.

7. Communist Party of Vietnam. (2000). The Complete Party Document episode 8. Hanoi: National politics.

8. Nguyen, M. H. (2006). Consistent implementation of the foreign policy of independence, peace, cooperation, and development. Journal of Communism. 12, 23-31.

9. Vu Khoan. (1993). Security, Development, and Influence in Foreign Affairs. International Studies 2, 3-11.

10. Communist Party of Vietnam. (1991). Document of the 7th National Party Congress. Hanoi: National politics.

11. Communist Party of Vietnam. (2011). The platform for building the country during the transition to socialism (Supplement, development in 2011). Hanoi: National politics.

12. Communist Party of Vietnam. (2011). Document of the 11th National Party Congress. Hanoi: National politics.

13. Communist Party of Vietnam. (2016). Document of the 12th National Party Congress. Hanoi: National politics. 